\title{
ULTIMATUM GAME WITH ASYMMETRIC INFORMATION: ASTUDY OF DECEPTION AND FAIRNESS
}

\author{
Stepan VESELY \\ Faculty of Arts, Masaryk University \\ Brno, Czech Republic \\ E-mail: stepan.vesely@seznam.cz
}

\begin{abstract}
The task of the experiment reported here is to examine decision making in ultimatum games with symmetric and asymmetric information. In the asymmetric information condition, subjects $(n=134)$ were given an opportunity to deceive their playing partner. I found that participants indeed deceived their partners, specifically: While subjects were given on average 108.06 (probabilistic) CZK (Czech Koruna) to divide among themselves and their partner, in the asymmetric condition they reported to their partner that they were given 59.05 CZK only. Subsequently, they allocated only $30.19 \mathrm{CZK}$ to their partner in the asymmetric information ultimatum game, whereas in the symmetric information game, where deception was not possible, they allocated $48.65 \mathrm{CZK}$. The larger the surplus to be divided, the more deception was present. Women deceived significantly more than men and allocated less money to their partner in the asymmetric information ultimatum game (the effect size of gender was small, though).
\end{abstract}

Key words: Ultimatum Game, deception, fairness, asymmetric information, gender differences

\section{INTRODUCTION}

The Ultimatum Game (UG) was introduced by Güth et al. (1982). UG rules are simple. It is a game for two players, usually with only one round. The players have a sum of money to be divided between them. One of the players is the proposer, the other is the responder. The roles are assigned randomly. The proposer makes an offer how to divide the money and the responder either accepts or rejects the offer. If the offer is accepted by the responder, the money is split according to the proposer's offer. However, if the

Acknowledgement: I would like to thank three anonymous referees for their valuable comments that helped improve the paper. responder rejects the offer, neither player gets anything. In both cases, the game is over.

In this paper I examine whether proposers tend to deceive responders when they have an opportunity due to asymmetric information: i.e., when responders do not know the size of the surplus to be divided and proposers can give them false information about it. Alternatively, proposers can play fair and give responders true information.

This paper builds upon Van Dijk et al. (2004) and Koning et al. (2011) and related research, but in my study the proposers deceived the other player actively (unlike in Van Dijk et al., 2004) and to a degree they themselves chose (unlike in both Van Dijk et al., 2004 and Koning et al., 2011).

My main research objectives, i.e., to study deception and fairness in a strategic setting,

DOI: $10.21909 / \mathrm{sp} .2014 .01 .650$ 
can be addressed by comparing the proposers' behavior under two information conditions: in an asymmetric information UG and in the standard UG.

I make the following predictions: Proposers will take advantage of the asymmetric information condition. Specifically, they will misrepresent the size of the surplus, especially in case of large surpluses. They will be less fair in the asymmetric information condition, which will show that they use fairness strategically in the standard UG, rather than having genuine preferences for fairness.

\section{THEORETICAL BACKGROUND AND FORMERRESEARCH}

From the game theoretic perspective, the proposer should offer the smallest fraction of the surplus to the responder, and the responder should accept it. A rational responder (that is someone whose utility function is monotonically increasing) should accept anything $>0$, because it maximizes his/ her gains (if he/she rejects, he/she will get $0)$. A rational proposer knows this, so he/she should offer the smallest fraction of the surplus $>0$ and have the rest for himself/herself. These moves represent the only subgame-perfect Nash equilibrium.

UG represents an attractive problem precisely because the players' behavior does not adhere to the game theoretic prediction outlined above. Proposers usually offer approximately $40 \%$ to $50 \%$ of the total sum, with $50 / 50$ split being the modal offer; and half of the responders usually reject offers below about $20 \%$ to $30 \%$ of the total sum, see, e.g., Güth et al. (1982), Fehr and Schmidt (1999), Croson et al. (2003).

\section{Fairness vs. Fear of Rejection}

According to the fairness hypothesis, proposers act fair (give high offers) even when they do not have to fear rejection. Conversely, according to the fear of rejection hypothesis, they propose relatively lower offers the less they have to fear rejection (see Suleiman, 1996).

Three main types of experimental design can be used to vary fear of rejection present in an UG setting: a comparison of UG and a dictator game, a comparison of modified UGs with different $\delta$ parameters, and a comparison of standard symmetric information UG and asymmetric information UG.

Kahneman et al. (1986), Forsythe et al. (1994), Hoffman etal.(1994), and Van Dijkand Vermunt (2000) relyon the first type of design: they compare the dictator game and the UG. In the dictator game there is no fear of rejection on the proposer's part because the responder cannot reject the proposer's offer, whereas in an UGhe/she can and in that case neither player gets anything (which is the scenario the proposer fears - ending up empty handed). The above mentioned authors theorize that if proposers give equally high offers, both in the UG and in the dictator game, it is due to their fairness preferences. If, on the other hand, proposers offer more in the UG than in the dictator game, it can be concluded that offers in the UG are partially driven by fear of rejection. Theresults of the aforementioned studies usually(with the exception of Van Dijk, Vermunt, 2000) support the fear ofrejection hypothesis ${ }^{1}$.

\footnotetext{
${ }^{1}$ All positive results from previous studies reported in this paper are statistically significant at least at the 5\% level.
} 
Suleiman (1996) and Van Dijk et al. (2004) modify the UG by including the discount factor $\delta$, which expresses the relative power of the responder to reject the offer made by the proposer. UG and dictator game are cases with extreme $\delta$ s $(0$ in case of UG and 1 in case of dictator game). The reasoning is analogical to that described in the previous paragraph: if proposers offer equally high offers, both in games with high $\delta$ s and in games with low $\delta$, it is due to their fairness preferences, otherwise higher offers in games with lower $\delta$ s are partially driven by fear of rejection. The findings of Suleiman (1996) and Van Dijk et al. (2004) support the fear of rejection hypothesis.

Finally, a comparison of standard symmetric information UG and asymmetric information UG was employed in Mitzkiewitz and Nagel (1993), Pillutla and Murnighan (1995), Straub and Murnighan (1995), Croson (1996), Kagel et al. (1996), Boles et al. (2000), Croson et al. (2003), Van Dijk and Vermunt (2000), Van Dijk et al. (2004), Shalvi et al. (2011b), and in the present paper. The basic comparison works on the same principle as in the two experimental designs outlined above: a comparison of the proposer's allocations in a low fear of rejection situation and in a high fear of rejection situation.

In this third type of design, the low fear of rejection situation is implemented as asymmetric information UG, whereas the high fear situation is the usual UG. Past findings on asymmetric information UG again support the hypothesis that offers in UG are partially driven by fear of rejection. For example, in Van Dijk et al. (2004) proposers divided a sum of chips under two conditions: symmetric information UG and asymmetric information UG. In both treatments the chips had double monetary value for the proposer. The asym- metric condition differed from the symmetric condition in that the responder did not know about the different value of chips. In the symmetric condition he/she was aware of it. Therefore, for any offer of $n$ chips there was presumably more fear of rejection in the symmetric than in the asymmetric condition. For instance, when the proposer offered 50 chips out of a 100-chip pie in both conditions, the responder perceived this as an equal split in the asymmetric condition, but as a 50 -forthe-responder/100-for-the-proposer split in the symmetric condition. As a result, in Van Dijk et al. (2004) the proposers offered more chips to the recipients in the symmetric information condition $(M=58.71)$ than in asymmetric condition $(M=50.56)$. Significant differences in the same direction between asymmetric information UG and standard UG are found by other studies, such as Straub and Murnighan (1995), Croson (1996), Croson et al. (2003) and Shalvi et al. (2011b).

\section{Deception in Asymmetric Information UG}

If the responder does not know the actual surplus size (or the actual value of the surplus to either of the parties), the proposer can take advantage of this and deceive the other, less informed player.

Most older studies of asymmetric information UG enable only indirect (passive) deception. That is the proposer cannot actively lie - he/she cannot explicitly state false size of the surplus or an incorrect value of the surplus. The proposer is only given the opportunity to behave as if the (incorrect) knowledge about the surplus size or the value of the surplus the other player has is in fact correct. We can return to the example from Van Dijk et al. (2004). A chip in the surplus has double monetary value for the 
proposer. The proposer knows it, the responder does not. The responder most likely incorrectly assumes that the chips have equal value for both players. Hence, the proposer is given the opportunity to behave as if the responder's incorrect assumption about the value of the chips was in fact correct. This constitutes the opportunity for indirect or passive deception. (Note that the proposer can alternatively behave in agreement with what is actually true about the value of the chips, which would lead to him/her making different distributive choices - namely compensating for the differential value of the chips by increasing his/her offer.)

In this paper I study the proposers' active deception. There seem to be only five older studies dealing with this topic: Boles et al. (2000), Croson et al. (2003), Koning et al. (2011) and two recent articles: Besancenot et al. (2013) and Kriss et al. (2013).

Koning et al. (2011) used modified UG and enabled active deception by proposers. Nevertheless, deception in their study had only two possible degrees (present - absent).

Kriss et al. (2013) designed an asymmetric information UG experiment where the proposer divided a surplus which was (with equal probability) either small or large. The receiver did not know the actual size of the surplus. The proposer could send a (possibly false) cheap talk message about the size of the surplus to the responder along with his/her offer.

Again, deception in Kriss et al. (2013) had just two possible degrees (present - absent).

In Boles et al. (2000) and Croson et al. (2003) subjects can only deceive the other player via cheap talk, so their design is somewhat different from the present one. In experiments with cheap talk (communication between players), the responder knows that the proposer delivers an unverifiable message (e.g., about the size of the surplus). In my experiment the situation is different - the responder can never tell whether information about the size of the surplus comes from the proposer, because all information is delivered to him/her by the experimenter. The information available in asymmetric information UG and in symmetric information UG is thus indistinguishable from the responder's perspective in my design ${ }^{2}$.

Besancenot et al. (2013) also use cheap talk type of communication. Otherwise, their study employs (independently) a design that is quite similar to mine: the actual surplus size is picked with even chances among integers in the interval $[50 ; 100]$. The distribution is common knowledge, however, the surplus size actually drawn is known only to the proposer who can misrepresent its size in a cheap talk message to the responder.

\section{Gender Differences}

Additionally, I want to check whether there are gender differences in decisions made in symmetric and asymmetric information UG. In the standard UG, there seem to be no robust gender differences in the proposers' distributive decisions (see, e.g., Solnick, 2001; Schmitt et al., 2008; McGee, Constantinides, 2013). As far as I know, no gender differences have been reported in the proposers' offers in partial information UG.

As Childs (2012) observes, the evidence whether men or women are more prone to deception is inconclusive (and he reviews some recent papers). For instance, Childs

\footnotetext{
2 This does not constitute deception on the experimenter's part, because all participants were informed about this procedure beforehand.
} 
(2012) found that equal portion of women and of men lied in a sender-receiver game. Similarly, Holm and Kawagoe (2010) found no notable gender differences in lying in this game. However, Dreber and Johannesson (2008) found that more men than women lied in this game. This is just one example of the mixed evidence regarding gender differences in deception. Therefore, I do not expect to find any strong gender differences.

The problem of gender differences in UG is tangential to this paper, but since gender differences in lying in strategic games represent a new area of study (see Dreber, Johannesson, 2008), I believe it could be of use to some readers to report my findings briefly.

\section{Where Next}

This article contributes to the investigation of active deception and fairness of distributional choices in strategic settings.

My first hypothesis (H1) is that surplus size stated by proposers in asymmetric information UG will be lower than the real surplus size. This is a test of the presence of deception.

Unlike the present study, most previous studies enabled only indirect/passive deception. More recently, a couple of studies enabled active deception via cheap talk messages (e.g., Croson et al., 2003; Besancenot et al., 2013). However, cheap talk communication may increase suspicion on the responder's part, since he/she is aware that the message about the surplus size he/she receives from the proposer can be false. Responder's suspicion is not a problem in my design, or much less so.

Like the present study, Koning et al. (2011) enable active non-cheap talk deception. The present design, however, enables many degrees of deception, whereas in Koning et al. proposers could choose between just two alternatives: to lie, or not, which is too restrictive.

My second hypothesis (H2) is that offers made in asymmetric information UG will be lower than offers in symmetric information UG. This is a test of the "fairness preferences" vs. the "fear of rejection" explanation of behavior in UG (cf. Suleiman, 1996; Van Dijk et al., 2004). If the null hypothesis is rejected, this will support the fear of rejection explanation.

Finally, I hypothesize that motivation to deceive increases with the size of the money at stake: misrepresentation of the surplus will be positively related to the size of the actual surplus (H3). This hypothesis is based on a simple notion that deception is safer and potentially more profitable in case of larger surpluses.

\section{METHOD}

\section{Participants}

A total of 134 subjects participated in this study (67 men, 67 women), mostly university students. Their age ranged from 17 to 58 years $(M=24.33, \mathrm{SD}=4.55)$. They were unsophisticated as far as UG is concerned. Although it is possible that some participants knew each other, they could neither choose, nor learn with who they interact.

\section{Procedures}

The study was presented to participants simply as a research on decision making. UG was explained to them in neutral terms (similarly to how the game is described in the In- 
troduction). Their comprehension was checked. Subsequently, they played six incentivized one-round UG games (players were rematched in each game), as described below in more detail.

All participants' decisions remained anonymous throughout the experiment. Only the experimenter knew each participant's decisions, i.e., the treatment was not double-blind (which was common knowledge) ${ }^{3}$.

The size of the surplus divided in each game ranged between 20 and 200 units of experimental Korunas (EK). The possible range of the surplus size was known to the subjects in both experimental conditions. The probability distribution over this range that determined the amount of money to be divided was not known to the participants. The mean actual surplus size and its distribution were identical in both experimental conditions in the sample as a whole. However, different participants experienced different selection of surplus sizes drawn from an underlying distribution (i.e., the surplus sizes were not the same for every participant and only randomized).

Participants were informed beforehand that $1 / 24$ of the games played for EK will be randomly selected and the amounts will be paid to the respective participants privately after completion of both stages of the experiment (with an exchangerate of $100 \mathrm{EK}=100 \mathrm{CZK}$ ).

\footnotetext{
${ }^{3}$ Such single-blind designs are common, although it is sometimes observed that players behave more pro-socially in single-blind than in double-blind experiments (see, e.g., Hoffman et al., 1994, 1996). However, according to Bolton et al. (1998) and Engel (2011) allocations in the dictator game (which is usually sensitive to factors in the experimental design) are independent of the presence vs. absence of experimenter observation.
}

The use of probabilistic money in decision experiments is common. For instancein Straub and Murnighan (1995) there was only a 2 out of 1813 chance that a particular decision will be chosen and rewarded in cash. In Van Dijk et al. (2004, Experiment 1) the chancewas 15 out of 108, in Boles et al. (2000) it was 50\%.

The experiment had two stages. In Stage 1, all participants had the role of the proposer. No feedback with respect to the acceptance of the proposals was given to them until after the experiment was completed. In Stage 2 all participants had the role of the responder. The offers from Stage 1 were randomly distributed among participants in Stage 2 to either accept, or reject them (more precisely, each participant received three offers made in each of the two experimental conditions described below). Participants were informed beforehand that the experiment will have these two stages and that the same people (including themselves) will participate in Stages 1 and 2.

In Stage 1 participants in the role of proposers made their decisions in six games: in three games in symmetric condition (SC) and in three games in asymmetric condition (AC). The order of presentation of SC and AC conditions was counterbalanced.

In SC the actual surplus size was known to both the proposer and the responder.

In $\mathrm{AC}$, the actual surplus size was known to the proposer, not to the responder. The proposer knew that the responder would not be given information about the actual surplus size. Instead, the surplus size stated by the proposer in Stage 1 was announced by the experimenter as the actual surplus size to the responder in Stage 2 (this procedure was common knowledge).

Therefore, in AC the proposer decided upon his/her division of the surplus and upon 
Table 1. Three illustrative examples of Stage 1 conditions

\begin{tabular}{|l|c|c|c|}
\hline & Symmetric condition & \multicolumn{2}{|c|}{ Asymmetric condition } \\
\hline Example no. & Example 1 & Example 2 & Example 3 \\
\hline Actual surplus size & 60 & 60 & 60 \\
\hline Surplus size stated by proposer & $\begin{array}{l}\text { Proposer cannot state } \\
\text { surplus size. }\end{array}$ & 40 & 60 \\
\hline $\begin{array}{l}\text { Surplus size announced to responder } \\
\text { as the actual surplus size }\end{array}$ & 60 & 40 & 60 \\
\hline Did proposer deceive the responder? & $\begin{array}{l}\text { Deception is not } \\
\text { possible. }\end{array}$ & Yes & No \\
\hline
\end{tabular}

the size of the surplus announced to the responder in Stage 2 as the actual surplus (this was the opportunity for active deception on the proposer's part).

The SC and AC conditions are illustrated by three examples in Table 1 .

Note that results from Stage 2 are not analyzed in this paper, because they are not related to my research objectives. Acceptance rate in stage 2 was $92.8 \%$ overall, fairly similar to e.g., Croson (1996).

\section{Measures}

The variables of interest are the following: the amount offered by the proposer in symmetric information UG, the amount offered by the proposer in asymmetric information UG, actual surplus size (manipulated by the experimenter), surplus size stated by the proposer in asymmetric information $\mathrm{UG}$, and two measures of misrepresentation of the surplus size by the proposer in asymmetric information UG, referred to as Misrepresentation $_{1}$ and Misrepresentation ${ }_{2}$. All variables are measured in units of EK.

By design, the stated surplus size must always be a multiple of $20 \mathrm{EK}$ and within the 20-200 range (the same is true for the actual surplus size).
The variable Misrepresentation equals 1 (stated surplus size / actual surplus size). In calculating Misrepresentation, but not Misrepresentation $_{1}$, cases of actual surplus equal to $20 \mathrm{EK}$ are ignored. The distinction between these two measures is made because deception has no sense - and it never took placewhen actual surplus is $20 \mathrm{EK}$.

\section{RESULTS}

With dependent t-test for repeated measures I supported hypothesis H1, i.e., the surplus size stated by proposers in Stage 1 in $\mathrm{AC}(\mathrm{M}=59.06, \mathrm{SD}=36.94)$ is lower than the respective actual surplus size $(\mathrm{M}=$ 108.06, $\mathrm{SD}=55.43), \mathrm{t}(401)=21.89, \mathrm{p}<.001$, effect size $r=.74$ (large effect $)^{4}$. The conclusion is that proposers deceive the other player in UG with asymmetric information, and the deception is substantial. $96 \%$ of subjects in this study deceived at least once and $43 \%$ deceived in all three game in AC.

With dependent t-test for repeated measures I supported hypothesis H2, i.e., offers in asymmetric information UG $(\mathrm{M}=30.19$, $\mathrm{SD}=18.39)$ are lower than offers in standard

\footnotetext{
${ }^{4}$ Individual decisions are used as observation units throughout the analyses.
} 
$\mathrm{UG}(\mathrm{M}=48.65, \mathrm{SD}=26.27), \mathrm{t}(401)=12.06$, $\mathrm{p}<.001$, effect size $\mathrm{r}=.52$ (moderate to large effect). This effect is presumably due to stronger fear of rejection, i.e. strategic play that involves the necessity of relatively higher offers in the SC condition.

To test H3 I calculate the correlation between two measures of misrepresentation of the surplus and the size of the actual surplus in AC. The average Misrepresentation $_{1}$ of surplus in $\mathrm{AC}$ is $0.386(\mathrm{SD}=0.285)$. When cases of actual surplus equal to 20 EK are ignored, the average Misrepresen-

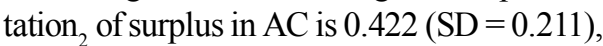
which corresponds to misrepresenting the actual surplus by $42.16 \%$. In 97 cases out of $402(24.13 \%)$ the proposers do not misrepresent the actual surplus in AC. When cases of actual surplus equal to $20 \mathrm{EK}$ are ignored, the actual surplus is not misrepresented in 63 cases out of $368(17.11 \%)$ in AC.

Pearson's correlation between misrepresentation of the surplus and the absolute size of the actual surplus in $\mathrm{AC}$ is $\mathrm{r}=.463$ $(p<.01)$ when computed for Misrepresentation $_{1}$ and $\mathrm{r}=.331(\mathrm{p}<.01)$ when computed for Misrepresentation 2 (i.e., when surpluses equal to $20 \mathrm{EK}$ are excluded). The correlation is positive, significant and moderate in size. This shows that proposers are somewhat more willing to deceive responders when larger pies are at stake, i.e. hypothesis $\mathrm{H} 3$ is supported.

\section{Additional Results}

Using t-test for independent samples, I found no significant differences between allocations by men $(\mathrm{M}=49.59, \mathrm{SD}=26.33)$ and women $(\mathrm{M}=47.72, \mathrm{SD}=26.23)$ in $\mathrm{SC}, \mathrm{t}(400)=$ $-0.71, \mathrm{p}=.476$.
However, with t-test for independent samples I discovered that offers made by women $(M=27.80, S D=18.12)$ in Stage 1 in AC were significantly lower than men's offers in that condition $(\mathrm{M}=32.58, \mathrm{SD}=18.39)$, $\mathrm{t}(400)=2.63, \mathrm{p}<.01$, effect size $\mathrm{r}=.13$, i.e., small effect.

I also found that women misrepresented the surplus size in AC more than men. Surplus size stated by men in $\mathrm{AC}(\mathrm{M}=63.78$, $\mathrm{SD}=37.01)$ was significantly larger than surplus size stated by women in $\mathrm{AC}(\mathrm{M}=54.33$, $\mathrm{SD}=36.35), \mathrm{t}(400)=2.58, \mathrm{p}<.05$, effect size $r=.13$ (small effect). Note that the average actual surplus size was the same for men and women.

To summarize, there seem to be no gender differences in distributive decisions in $\mathrm{SC}$ and some small differences in distributive decisions and in active deception in AC.

\section{DISCUSSION}

I confirmed that offers in asymmetric information UG were lower than offers in standard UG. This is in line with previous studies that involved asymmetric information $\mathrm{UG}$, e.g., Straub and Murnighan (1995), Croson (1996), Van Dijk and Vermunt (2000), Van Dijk et al. (2004).

I can add that the average offer made in SC was equal to $45.02 \%$ of the pie, hence comparable to the normally observed values (e.g., Fehr, Schmidt, 1999).

It is worth noting that the average offer made in AC was equal to $51.13 \%$ of the stated size of the pie. Therefore, both in SC and AC proposers offered roughly an equal share of the "visible" surplus. This indicates that even when the proposer does not in fact behave fairly, he/she feels the need to ap- 
pear as if he/she did. One aspect of the results reported by Van Dijk and Vermunt (2000) also suggests this. Proposers in their second experiment divided 100 chips. In the asymmetric information condition where responders were uncertain whether the surplus was 60 or 100 chips, $32 \%$ of the proposers offered 30 chips (i.e., a fair split if the surplus was 60 chips), whereas none of the participants made such an offer in the symmetric information condition.

This hint of indirect deception in Van Dijk and Vermunt (2000) leads us to the results related to my main hypothesis. I found that proposers deceived the other player in UG with asymmetric information and the deception was substantial.

$96 \%$ of the subjects in the present study deceived at least once and $43 \%$ deceived in all three games in AC. The proportion of cases where deception was present was $82.88 \%$ (when cases with actual surplus equal to $20 \mathrm{EK}$ are ignored). These results are broadly in accord with Boles et al. (2000), Koning et al. (2011), Besancenot et al. (2013) and Kriss et al. (2013).

In Koning et al. (2011) proposers in a modified UG actively deceived in $52.27 \%$ of the cases. Kriss et al. (2013) found a 67\%-89\% proportion of subjects who send untrue messages. Active deception is roughly equal or somewhat more prevalent in my experiment. However, the present design enables various levels of deception. In Koning et al. (2011), it was only possible to either state that the chips had double value for the proposer (i.e., not to deceive), or state that it has equal value for both players (i.e., deceive). In Kriss et al. (2013) the situation was basically the same. It is therefore quite likely that those subjects, who in the current study deceived to a small degree, would have been honest in Koning's et al. or Kriss's et al. experiments where small degree of active deception was impossible. Hence, qualitatively speaking, the tendency toward active deception does not seem to be more prevalent in my experiment than in Koning et al. (2011) and Kriss et al. (2013).

In Besancenot et al. (2013) the proportion of false stated surplus sizes was $88.5 \%$, i.e., very similar to my result ( $82.88 \%)$. Misrepresentation of the endowment was, however, roughly two times smaller in Besancenot et al. (2013), namely $20.5 \%$ (whereas it was $42.16 \%$ in my experiment). Differences in experimental design could perhaps account for this difference. Most notably, in our case, 1 in 24 games was randomly selected and paid in cash, while in Besancenot et al. (2013), it was 1 in 4 games. We can speculate that proposers may realize that the monetary benefit from deception should be discounted by the subjective probability that their decisions will be actually picked for payment. This subjective discount factor is most likely higher in my experiment. Thus, subjects who presumably take this subjective discount factor into account would need to misrepresent the surplus more in my experiment than in Besancenot et al. (2013), which is in line with the data. Also, cheap talk type of communication in Besancenot et al. (2013) could have diminished the level of deception.

I also showed that proposers were somewhat more willing to deceive responders when larger endowments were at stake. This is in line with Gneezy (2005) who found that players in a sender-receiver game lied more if they could gain more. Besancenot et al. (2013) also report some descriptive results that support the existence of a positive relationship between actual surplus size and the degree of misrepresentation; Boles et al. 
(2000) also give some descriptive results supporting this finding.

As far as gender differences are concerned, I found no gender differences in distributive decisions in SC (which is in line with, e.g., Solnick, 2001; Schmitt et al., 2008; Šeneklová, Špalek, 2009) and some small differences in distributive decisions and in active deception in AC.

Given the generally mixed and/or negative results regarding differences in deception by gender (see e.g., Holm, Kawagoe, 2010; Childs, 2012, and studies quoted therein) and practically no previously published findings on gender differences in deception in asymmetric information UG, any conclusive interpretation of my findings appears premature at least before they are found on replication. I would also recommend obtaining motivational information and beliefs from the proposers, since it may be the case that different motives and beliefs are triggered in female proposers (previous research for example indicates that women are less competitive than men - see e.g., Niederle, Vesterlund, 2007; Kusá, 2010), which might lead to different degree of deception in UG.

The main reason for deceiving others is usually self-interest. According to standard economic theory, people will lie whenever they can benefit from it and the possible costs are not too high (see e.g., Gneezy, 2005). In the present case there is money at stake players can increase the likelihood of securing more money when they lie about the surplus.

On the other hand, there are usually reasons not to deceive others or to use deception only to a certain degree. This is evidenced by the fact that subjects in the current experiment misrepresented the actual surplus size just to a certain degree. On the one hand, this can be explained by the fact that the range of surplus sizes was common knowledge and proposers might have assumed that for low observable surplus sizes responders could suspect deception to be present (which might be thought to increase the risk of rejection). On the other hand, a complementary explanation is that deception comes at a psychological cost, such as feeling guilt, shame, embarrassment or fear, and/ or damaging one's self-concept as an honest person.

This psychological cost of deception and the related intrinsic aversion of deceiving others can have several different sources, which are an object of lively research and debate (see e.g., Mazar et al., 2008; Lundquist et al., 2009; Shalvi et al., 2011a, 2011b). It is not the purpose of the current paper to identify the sources of the possible psychological cost of deception (a different design would be necessary), so only a brief overview follows.

Sánchez-Pagés and Vorsatz (2007) argue that people refrain from deception because they follow a truth-telling moral norm (breaking the norm would arguably result in a psychological cost to oneself). This view is indirectly supported by questionnaire data from Gneezy (2005) where 88-98\% of participants rated lies described in two scenarios as (very) unfair. Mazar et al. (2008) posit that the norm of being honest is internalized as a part of self-concept. Subsequently, behaving dishonestly bears negatively on one's self-concept, which is aversive. Overall, Mazar's et al. results support the view that paying attention to moral norms (e.g., when being reminded of them) curbs dishonest behavior.

Mazar et al. (2008) also study certain mechanisms by which the need to update one's 
self-concept after behaving dishonestly can be attenuated, such as rationalization and inattention to standards for honesty. Related to this, Shalvi et al. (2011a) show that the psychological cost of lying can be moderated by the ability to subjectively justify one's deception.

Lundquist et al. (2009) found that, all things being equal, aversion to lying increases in the size of the lie: i.e., subjects are more likely to lie when a small lie is sufficient to benefit them (while they are less likely to lie when a large lie is necessary to obtain the same benefit). Notice that this finding cannot be easily applied to my results, because in my experiment a small lie would typically yield a smaller (not the same) expected benefit than a large lie. Lundquist et al. (2009) also suggest aversion to lying is weaker when subjects believe other participants lie.

Finally, Gneezy (2005) found that aversion to lying decreases in one's own potential payoff secured by lying, while it increases, if the lie harms others. Following Gneezy (2005) we can, for example, reason that the degree to which a proposer lies strikes a balance between the effect (on lying) of his/her own expected gain obtained from lying and the effect of the expected reduction of the responder's gain. However, it is not possible to conclude which variables (such as those studied by Gneezy, Sánchez-Pagés and Vorsatz, Lundquist et al., Mazar et al.) actually influence deception in my design. It could be interesting to undertake a comprehensive study of these factors in the future.

As pointed out by Boles et al. (2000, p. 256), UG is an "abbreviation" of more complex negotiations and research in more naturalistic settings is therefore called for. For example, Lusk et al. (2006) and Levitt and List (2007) argue that behavior of subjects in laboratory experiments (where they know their behavior is under systematic scrutiny) is prone to be more pro-social and moral than in more natural settings. Hence, we might possibly expect even more deception in comparable real-life situations. On the other side, in real life the moral norm of truth-telling can be more salient, which could lead to less deception. Also, in the lab lying can be possibly more easily categorized by the participant as something else than "lying" (e.g., as "competing"), which can protect his/her selfconcept of an honest person despite deception (see Mazar et al., 2008).

The current study somewhat enhances the realism of experimental research on deception in UG by enabling active deception in various degrees (which is its main advantage over the sender-receiver game design and over Boles et al., 2000; Croson, 2003; Koning et al., 2011; and Kriss et al., 2013). A recent study, independently, used a similar design - see Besancenot et al. (2013). It might be interesting to include different forms of possible deception in prospective studies (e.g., face-to-face and written) between which the participants could choose and to investigate their "attractiveness" to pro-posers (maybe moderated by personality traits) and their "effectiveness" in deceiving the responders.

Deception is not uncommon in real-life bargaining and negotiation (see e.g., Boles et al., 2000; Van Dijk et al., 2004, and references therein). When bargaining under incomplete information (e.g., when the private values of the stake are not publicly disclosed), UG with asymmetric information can be a particularly useful model. The results I obtained from this model situation show that subjects use active deception quite extensively to further their profit. 
Among the options of dealing with this problem in real life is the assessment of situational and dispositional factors that can influence the amount of deception. Since bargaining for larger stakes increases the degree of deception, it could be wiser to bargain for a number of smaller stakes (perhaps with independent parties), rather than for one large stake. Also, certain personality characteristics such as social value orientation can predict deception (see Van Dijk et al., 2004; Sakalaki, Sotiriou, 2012).

Because in real life deception is usually detectable to a certain degree, the possibility of discovering the proposers' misrepresentations could be introduced into prospective studies. This could lead to an interesting and meaningful investigation of learning in strategic settings (see e.g., Nagel, Tang, 1998; Golman, Page, 2010; Veselý, 2012, for other examples). Several effects might be examined: 1) the willingness of the responder to pay for an increased likelihood of detecting deceit; 2) the adaptation of the proposer to the level of detectability; 3 ) the adaptation of the level of detectability by the responder in response to the proposer's changing (adaptive) behavior.

Received January 20, 2013

\section{REFERENCES}

BESANCENOT, D., DUBART, D., VRANCEANU, R., 2013, The value of lies in an ultimatum game with imperfect information. Journal of Economic Behavior \& Organization, 93, 239-247.

BOLES, T.L., CROSON, R.T.A., MURNIGHAN, J.K., 2000, Deception and retribution in repeated ultimatum bargaining. Organizational Behavior and Human Decision Processes, 83, 235-259.

BOLTON, G.E., KATOK, E. ZWICK, R., 1998, Dictator game giving: Rules of fairness versus acts of kindness. International Journal of Game Theory, 27, 269-299.
CHILDS, J., 2012, Gender differences in lying. Economics Letters, 114, 147-149.

CROSON, R.T.A., 1996, Information in ultimatum games: An experimental study. Journal of Economic Behavior \& Organization, 30, 197-212.

CROSON, R.T.A., BOLES, T., MURNIGHAN, J.K., 2003, Cheap talk in bargaining experiments: Lying and threats in ultimatum games. Journal of Economic Behavior \& Organization, 51, 143-159.

DREBER, A., JOHANESSON, M., 2008, Gender difference in deception. Economics Letters, 99, 197199.

ENGEL, C., 2011, Dictator games: A meta study. Experimental Economics, 14, 583-610.

FEHR, E., SCHMIDT, K.M., 1999, A theory of fairness, competition, and cooperation. Quarterly Journal of Economics, 114, 817-868.

FORSYTHE, R., HOROWITZ, J.L., SAVIN, N.E., SEFTON, M., 1994, Fairness in simple bargaining experiments. Games and Economic Behavior, 6, 347-369.

GNEEZY, U., 2005, Deception: The role of consequences. American Economic Review, 95, 384394.

GOLMAN, R., PAGE, S.E., 2010, Individual and cultural learning in stag hunt games with multiple actions. Journal of Economic Behavior \& Organization, 73, 359-376.

GÜTH, W., SCHMITTBERGER, R., SCHWARZE, B., 1982, An experimental analysis of ultimatum games. Journal of Economic Behavior \& Organization, 3, 367-388.

HOFFMAN, E., MCCABE, K., SHACHAT, K., SMITH, V., 1994, Preferences, property rights, and anonymity in bargaining games. Games and Economic Behavior, 7, 346-380.

HOFFMAN, E., MCCABE, K., SMITH, V.L., 1996, Social distance and other-regarding behavior in dictator games. American Economic Review, 86, 653-660.

HOLM, H.J., KAWAGOE, T., 2010, Face-to-face lying: An experimental study in Sweden and Japan. Journal of Economic Psychology, 31, 310-321.

KAGEL., J., KIM, C., MOSER, D., 1996, Fairness in ultimatum games with asymmetric information and asymmetric payoffs. Games and Economic Behavior, 13, 100-110.

KAHNEMAN, D., KNETSCH, J.L., THALER, R.H., 1986, Fairness and the assumptions of economics. Journal of Business, 59, S285-S300.

KONING, L., STEINEL, W., VAN VEEST, I., VAN DIJK, E., 2011, Power and deception in ulti- 
matum bargaining. Organizational Behavior and Human Decision Processes, 115, 35-42.

KRISS, P.H., NAGEL, R., WEBER, R.A., 2013 , Implicit vs. explicit deception in ultimatum games with incomplete information. Journal of Economic Behavior \& Organization, 93, 337-346.

KUSÁ, D., 2010, Representations of psychological interdependence in males' and females' expectations of hierarchy and competition. Studia Psychologica, 52, 193-206.

LEVITT, S.D., LIST, J.A., 2007, What do laboratory experiments measuring social preferences reveal about the real world? Journal of Economic Perspectives, 21, 153-174.

LUNDQUIST, T., ELLINGSON, T., JOHANNESSON, M., 2009, The aversion to lying. Journal of Economic Behavior \& Organization, 70, 81-92.

LUSK, J.L., PRUITT, J.R., NORWOOD, B. 2006, External validity of a framed field experiment. Economics Letters, 93, 285-290.

MAZAR, N., AMIR, O., ARIELY, D., 2008, The dishonesty of honest people: A theory of self-concept maintenance. Journal of Marketing Research, $45,633-644$.

MCGEE, P., CONSTANTINIDES, S., 2013, Repeated play and gender in the ultimatum game. Journal of Socio-Economics, 42, 121-126.

MITZKIEWITZ, M., NAGEL, R., 1993, Experimental results on ultimatum games with incomplete information. International Journal of Game Theory, 22, 171-198.

NAGEL, R., TANG, F.F., 1998, Experimental results on the centipede game in normal form: An investigation on learning. Journal of Mathematical Psychology, 42, 356-384.

NIEDERLE, M., VESTERLUND, L., 2007, Do women shy away from competition? Do men compete too much? Quarterly Journal of Economics, 122, 1067-1101.

PILLUTLA, M.M., MURNIGHAN, J.K., 1995 Being fair or appearing fair: Strategic behavior in ultimatum bargaining. Academy of Management Journal, 38, 1408-1426.

SAKALAKI, M., SOTIRIOU, P., 2012, Pro-self orientation and preference for deceitful strategies: Social value orientation, dispositional and behav- ioral correlates of economic opportunism. Studia Psychologica, 54, 157-165.

SÁNCHEZ-PAGÉS, S., VORZATZ, M., 2007, An experimental study of truth-telling in a sender-receiver game. Games and Economic Behavior, 61, 86-112.

SCHMITT, P., SHUPP, R., SWOPE, K., MAYER, J., 2008, Pre-commitment and personality: Behavioral explanations in ultimatum games. Journal of Economic Behavior \& Organization, 66, 597-605

ŠENEKLOVÁ, J., ŠPALEK, J., 2009, Jsou ekonomové jiní? Ekonomický model versus realita. [Are economists different? Economic model vs. reality]. Politická Ekonomie, 57, 21-45.

SHALVI, S., DANA, J., HANDGRAAF, M.J.J., DE DREU, C.K.W., 2011a, Justified ethicality: Observing desired counterfactuals modifies ethical perceptions and behavior. Organizational Behavior and Human Decision Processes, 115, 181 190.

SHALVI, S., HANDGRAAF, M.J.J., DE DREU, C.K.W., 2011b, People avoid situations that enable them to deceive others. Journal of Experimental Social Psychology, 47, 1096-1106.

SOLNICK, S., 2001, Gender difference in the ultimatum game. Economic Inquiry, 39, 189-200.

STRAUB, P.G., MURNIGHAN, J.K., 1995, An experimental investigation of ultimatum games: Information, fairness, expectations, and lowest acceptable offers. Journal of Economic Behavior \& Organization, 27, 345-364.

SULEIMAN, R., 1996, Expectations and fairness in a modified ultimatum game. Journal of Economic Psychology, 17, 531-554.

VAN DIJK, E., VERMUNT, R., 2000, Strategy and fairness in social decision making: Sometimes it pays to be powerless. Journal of Experimental Social Psychology, 36, 1-25.

VAN DIJK, E., DE CREMER, D., HANDGRAAF, M.J.J., 2004, Social value orientations and the strategic use of fairness in ultimatum bargaining. Journal of Experimental Social Psychology, 40, 697707.

VESELÝ, Š., 2012, Effect of learning in the Prisoner's Dilemma game. Studia Psychologica, 54, 143-156. 


\title{
ULTIMATIVNÍ HRA S ASYMETRICKOU INFORMACÍ: STUDIE KLAMUAFÉROVOSTI
}

\author{
Š. V e s e 1 ý
}

Souhrn: Cílem experimentu bylo zkoumat rozhodování v ultimativní hře se symetrickou a asymetrickou informací. V podmínkách asymetrické informace byla účastníkům $(\mathrm{n}=134)$ dána možnost klamat své protihráče. Zjistil jsem, že účastníci své protihráče skutečně podváděli, konkrétně: Zatímco účastníci měli mezi sebe a své protihráče rozdělit v průměru 108,06 (pravděpodobnostních) Kč, v podmínkách asymetrické informace sdělili svému protihráči, že rozdělovat se bude pouze $59,05 \mathrm{Kč}$. V ultimativní hře s asymetrickou informací účastníci následně přidělili svým protihráčům průměrně pouze 30,19 Kč, zatímco v ultimativní hře se symetrickou informací, kde klamání nebylo možné, přidělili průměrně 48,65 Kč. Č́ím větší částka měla být rozdělována, tím větší byla míra podvádění. Ženy v ultimativní hře s asymetrickou informací klamaly své protihráče signifikantně více než muži a přidělovaly jim menší částky (nicméně velikost efektu genderu byla malá). 